\title{
THOMAS BRAGA'S PORTINGALES: A CELEBRATION OF PORTUGUESE AMERICAN CULTURE
}

\section{Reinaldo Silva}

Profoundly fascinated by and connected to the ancestral culture, Thomas Braga in Portingales (1981) believes he can best express his condition as a socalled hyphenated American if he expresses himself in English rather than in Portuguese. Fully aware that English, as opposed to Portuguese, will connect him with broader audiences so as to convey his ethnic experience, Braga's poems are subtle reminders to mainstream America of the enormous contributions of the peoples of Portuguese descent to the building of the United States of America.

While focusing on the complexities of being born and growing up as a hyphenated native of the United States, Braga is also eager to celebrate Portuguese American heroes, express the Portuguese reaction to mainstream values and beliefs, and show how Portuguese values and traditions are kept alive within a dominant culture, particularly through his grandmother, whom he views as a connecting bridge for the country and culture of Braga's ancestors. 


\section{Ethnic Studies Review Volume 27: 1}

In "'The Poor, Shiftless, Lazy Azoreans': American Literary Attitudes Toward the Portuguese," published in1979, George Monteiro noted that "perhaps the Portuguese in America will get a fairer shake from that first-rate novelist of Portuguese descent who has yet to make his appearance." At the time no one knew "what that first-rate (or second-rate or tenth-rate) writer will write about the Portuguese, if that writer deigns to write about them at all." Monteiro goes on to state, "If the writer chooses to ignore the American Portuguese he or she will not have been the first one to do so, for the sad fact is that the United States already boasts in its cultural history two writers of Portuguese descent" (Monteiro 186). Before embarking on a detailed analysis of why Thomas Braga's poetry in Portingales should take its place as Portuguese American literature, a brief outline of the few writers who preceded him might prove helpful. In other words, this category within American Literature, how it evolved, and the ways in which these voices responded to American culture and traditions need to be addressed.

The first two authors under consideration are John Dos Passos (1896-1970), a writer who is well known for his novels about America, and John Phillip Sousa (1854-1932), a renowned composer and concertmaster. It is less recognized that Sousa was also the author of three novels and an autobiography. In the fiction, The Fifth String, a novelette published in 1902; Pipetown Sandy, a novel published in 1905 for young readers; and The Transit of Venus, which appeared in 1919,Monteiro notes, there is "nothing...that remotely touches on Sousa's ethnicity" (187).

John Dos Passos was the grandson of an immigrant from the island of Madeira. He did not acknowledge let alone celebrate his Portuguese ancestry. Monteiro notes that Dos Passos felt uncomfortable with Salazar's fascist dictatorship in Portugal (1926-1974) and that he had identity problems from the beginning since he had been born out of wedlock and his father was considered a "Dago." His magnificent major work, USA (1930), composed of three volumes or novels-The 42nd Parallel, Nineteen Nineteen, and The Big Money--does not include any reference to his Portuguese background. Nor does Mid-Century (1960) in which Dos Passos chronicles the mid-twentieth centu- 
ry in the United States as USA does the 20s and early 30s. Nor does Mr. Wilson's War (1962), a selection from, ironically, the Mainstream of America Series, covering the time from the assassination of McKinley to the defeat of the League of Nations. With the exception of the later phase in his career, when he wrote books about Brazil and Portugal as was the case with The Portugal Story: Three Centuries of Exploration and Discovery, published in 1969, Monteiro notes that his Portuguese ancestry "was more of an encumbrance to be suffered quietly than a proud heritage worthy of proclamation"(196).

Although we find ethnic literature early on in American Literature, for example Abraham Cahan's The Rise of David Levinsky (1917), Anzia Yezierska's Bread Givers (1925), and certainly as early as 1845 in the slave narrative, Narrative of the Life of Frederick Douglas, these were works written by immigrants still familiar with their native country and customs or in the latter case in response to the institution of slavery. Sousa and Dos Passos must be understood in the context of the times and culture which shaped them. First of all, both Sousa and Dos Passos were born in the United States and viewed themselves as Americans; this meant denying one's ethnic background, viewing it as an obstacle to breaking into the Anglo cultural mainstream. They stand as symbols of ethnically dispossessed people due to the pressures mainstream American culture placed on its non-Anglo citizens, especially those with artistic yearnings and especially in the first half of the century.

Fortunately, more recent writers have not felt so alienated from their ethnic background. Instead they more often have seen in their heritage a richness worth celebrating and writing about. With Thomas Braga (and more recently Frank X. Gaspar and Katherine Vaz) Portuguese American literature has matured to the point of aptly being classified as such. Gaspar's Leaving Pico (1999) and Vaz's Mariana (1997) are two examples of Portuguese American fiction that have kicked open the door to mainstream American Literature and are widely read and appreciated in America and abroad. Their appeal to a wider audience is obviously greater than those of the former emigrant/exile or immigrant generation of writers such as José Rodrigues Miguéis (1901- 


\section{Ethnic Studies Review Volume 27: 1}

1980) and Jorge de Sena (1919-1978), who wrote mostly in Portuguese.

The major difference between Miguéis and Sena and emergent Portuguese American writers such as Gaspar, Vaz, and Braga is that the voices composing the latter group write in English. Neither Gaspar nor Vaz know Portuguese well enough to write in the language their writing. In addition, these are three voices among a few others whose arrival may counteract the absence Monteiro complained about nearly a quarter of a century ago.

In an interview conducted by Nancy T. Baden and published in 1981, one of her interviewees, Onésimo Teotónio Almeida, when asked about the possibility of the emergence of a Portuguese American ethnic literature, he observed that if it ever emerged, it certainly would be written in English and would be classified as belonging to American Literature (Duarte 26). Such is the case with the poetry in the work under consideration. In Portingales (1981), however, Braga does not completely dismiss the language of his ancestors since at least four poems have Portuguese versions. Once in a while he will also sprinkle some of his poems with a word or two of Portuguese. What this seems to indicate is his strong attachment to the culture of his ancestors. Braga has also published the following volumes: Chants Fugitifs (1981), poems written in French and reflecting the poet's graduate school days; Coffee in the Woodwinds (1990), a work inspired by the habitués of a coffee shop in Plattsburgh, New York, where the poet got to hear the concerns and sounds (accents) of the locals; Crickers' Feet (1992), poems where the poetic voice views the activities of locals from the "catbird's" seat; Borderlands (1994), where Braga collected his foreign language poems in French, Portuguese, and Spanish to fathom the "borderlands" of the heart; Litotes (1997), poems written in a subdued sensuous style; Motley Coats 2001), poems departing from the purely ethnic theme to embrace a wider world view; Inchoate: Early Poems (2003), containing the poet's very first attempts while an undergraduate and graduate student. He has just completed Amory: Six Dialogues and Six Poems, a prose piece interspersed with poetry, which is still awaiting publication. It consists of six short dialogues between Amory, an eighty- 
one year-old Portuguese American man near the end of his life, and Tony, a thirteen year-old Portuguese American lad. They talk about a number of controversial topics including sexuality, love and marriage, poetry and literature in general, God, religion and death, and homosexuality. My analysis of Braga is limited to his Portuguese American experience to Portingales since this is the only one dealing exclusively with that experience. In this volume, Braga claims to have expressed his obsession with a bilingual childhood and ethnic identity, aspects that do not emerge as strongly in his other volumes.

But who is Braga? We learn the following in George Monteiro's preface to Portingales:

Thomas Braga is of Portuguese ancestry. Born in Fall River [Massachusetts], on Columbia Street (still very much at the heart of the city's Portuguese community), he remains-willy-nilly-a hyphenaed American. As a tenured university teacher, his primary field is the French language and its literature, with, officially, secondary interests in other romance languages, including the language of his parents and ancestors (11).

Although Braga's poems should not be described as being essentially Portuguese American, Monteiro is of this opinion:

[It is] absolutely right to call them the poems of a poet who happens to be a Portuguese-American. That is not to say that his poems never touch upon the complexities of being born and growing up as a hyphenated native of the United States. On the contrary; for although some of the poems actually center on that complex experience, all the poems, in my estimation, derive from that same experiential situation (12).

Further evidence that Braga thoroughly partakes in the culture and language of his ancestors is his dedicating Portingales to "Vovó," that is, his grandmother. As we shall see in some of his poems, this woman is an emblematic figure because she represents the ties with the culture of the Azores islands in the Atlantic nearly a thousand miles west of mainland Portugal.

Portingales is a collection of twenty-seven poems, namely: "Friendship" or "Amizade"; "Solitude" or "Solidão"; "Azorean 


\section{Ethnic Studies Review Volume 27: 1}

Portingale" or "Açoriana"; and "In the Glass Dome" or "Na Redoma." The poems can be grouped into one major category, with two subgroups: the celebration of Portuguese American heroes and the ancestors. The first group deals with writings that touch upon matters related to ethnicity: the celebration of Portuguese American heroes as part of a Portuguese reaction to denigrating mainstream values, beliefs, and practices. It also focuses on Portuguese values and traditions and how they are kept alive within a dominant culture that has traditionally encouraged ethnic minorities to assimilate and forget their ancestral culture. The poems in this group also highlight what is quintessentially Portuguese. The second group deals with Braga's ancestors and how they relate to retaining their ethnic culture.

What is perhaps the most interesting aspect of "Below the Hill," a poem from the first subgroup, is how Braga views his city of birth and its clannishness and schooling as a stifling wasteland during one of his

Digressions
through haunted Ghetto
and stagnant streets
ramble once again
in the Psyche
of a too reflective

Ego (17). 1

Braga's command of written Portuguese shows that he took lessons in Portuguese. In the following quote, he touches upon an aspect of Portuguese American life in the United States. Parents who wish to maintain their ties with their country of origin often enroll their children in the community's Portuguese school in the evening. His childhood recollections of the school he attended are so vividly imprinted on his mind that he even refers to them during one of his strolls through the streets of Fall River:

On the other side, Escola, where crucifying hours taught 
Subject to "have"

Knowledge,

but not to love

Truth (19).

The poem also contains a few snapshots of the people in this community, the poet's house of birth, the church he attended, and the city, which is compared to a wasteland. In addition this poem also stresses how learning the language and clannishness are ways of retaining ethnicity even if at times Braga makes these sound negative. Perhaps the most important feature of "Below the Hill" is the way that the poet views himself in relation to this ethnic community and how it has shaped his personality and outlook on life. With such a background it is obvious he would see life with Portuguese American eyes:

It is I - 'Guee who speak,

inviting Anyone

to walk with me

and peek at Corners

of Obsessions'

Soul (17).

The phrase "I - 'Guee" may also mean something else. If we isolate it from the rest of the poem it may not only represent the emphasis he places on himself as someone who has been shaped by Portuguese culture. In a broader sense he may be hinting at how a hyphenated American spends most of his life shifting back and forth from the private sphere of his ancestral culture and that of the public, official mainstream represented by school or one's profession, an aspect Richard Rodriguez has touched upon in Hunger of Memory: The Education of Richard Rodriguez. Moreover, Braga might be pointing to his status as a "Guee" whose other self is constantly being challenged by the demands of a mainstream culture based on the principles of self-reliance and individualism, here represented by the "I."

The poem, "Independence," is Braga's reminder to mainstream culture of the Portuguese presence, here symbolized in the figure of John Phillip Sousa during the celebration of a key date in American culture, Independence Day: 
With Sousa marches we parade

through city streets, parks and suburbs,

pageantries democratized, e

pluribus, we have an unum.

Can anyone, Braga asks, imagine a Fourth of July parade (or any parade in the United States) without patriotic marches? The irony this poem uncovers is that mainstream culture has often neglected the contributions of its ethnic minorities, but on Independence Day it cannot do without the music of Sousa, a Portuguese American. Compared to the quoted excerpt, the second strophe is longer. While the first one stresses Sousa's contributions to American culture, the second one deliberately presents mainstream culture more forcefully so as to show how it dilutes its ethnic component:

We civilize with bubble gum, soda, libations Amerindian, England's laws made new Saxon constitution, space's self-reliance.

But man in every state remains What his species earns, compliance, and builds upwards a politic, a striped cause for identity.

Adam calls home earth endemic, all governments disassociate, all master plans proliferate metamorphic conformity (53).

It is in the complexity of these lines where Braga's argument actually lies. When alluding to Emerson and Whitman through the references to "self-reliance" and "Adam," Braga is certainly elevating Sousa to a similar status. With Sousa there is certainly a little bit of Portugal in Independence Day. Instead of referring to these festivities as Fourth of July parades, Braga deliberately alludes to them as "Sousa marches" so as to acknowledge his ancestry. Apart from this poem's stress on ethnic allegiance, Braga is also expressing the pride he feels in sharing the same ethnic background as Sousa especially when he and other fellow Americans proudly parade "through city streets" at the beat of "Sousa marches." In addition, this poem is a reminder of what 
has gotten lost, that is, one's ethnic identity, at a time when the official discourse in America urges ethnic minorities to assimilate as quickly as possible and forget their ethnic background. In Braga's words, Americans have been urged to adopt the values of "compliance" and "metamorphic conformity," while showing us how this philosophy leaves ethnic minorities completely depersonalized.

A quick glance at the poem, "Judith Melo," suggests a criticism of the practice of Anglicizing foreign names, but an indepth analysis reveals that it is more than an affirmation of one's ethnic background. Below a surface reading lie important historical matters other than the marriage of a Portuguese Jew and a Portuguese Catholic:

Judith Melo,
come, make litanies
with Luso Manuel
and let sullen
Providence
smile, sneer, smite
your dark Semite
countenance.

The priests and I remember dolefully Judy pouting, whispering reverently:

'I hate the name Judy;

my name is Judith Melo.'

In this poem what Braga aims at uncovering for mainstream readers is the role of Portuguese Jews in America and how much they have contributed to the grandeur of this nation. According to Pap:

Portuguese Jews [were] driven from Portugal, first by the forcible conversion order of 1496 and then by the continuous persecutions (even of those who had forcibly embraced Catholicism) throughout the six- 
teenth and seventeenth centuries. Other Jews of Portuguese descent, together with many originating from Spain had found refuge in England and in eastern Mediterranean countries. During the second half of the seventeenth century, and through the eighteenth, many of these Spanish-Portuguese (Sephardic) Jews made their way to the American colonies (Pap 9-10).

One particular group settled in Newport, Rhode Island, where they "laid the cornerstone of what is now the oldest extant synagogue in America, the Touro Synagogue in Newport." Moreover, Portuguese Jews were instrumental in introducing the sperm-oil industry to America:

...The development of Newport under Aaron Lopez and his associates helped pave the way for the leading role which New England was to take in whaling in the nineteenth century, with New Bedford as the center. It is likely that the whaling ships operated by Lopez, like those going out from Nantucket and New Bedford in later years, recruited part of their crews in the Azores, and thus provided the 'jumping board' for some of the earliest Azorean settlers in the American colonies (Pap 11-12).

Not only have the Portugese Jews founded the oldest synagogue in America they also have contributed with their expertise to one of the most financially-rewarding industries in nineteenthcentury America, especially in New Bedford and Nantucket. That is why words such as "Newport," "Sephardic," "candles" and "Converso" (a Jew or Muslim who has converted to Christianity) in Braga's poetry are meaningful, as the following lines show:

Judith at Mass

celebrated at Newport

heard the non sum dignus echoing with the candles. Judy sighed and giggled While the choir, incense, temple lisped Sephardic chants, melo-dias. 
Judith Melo,

forget the tribe,

forsake the tiles

Converso,

mememtoes of crucified

Book - Azulejo.

Call me your spouse

Ecclesiastical (57-58).

The whales and the sperm oil, after all, were all transformed into the "candles" that this poem alludes to and which illuminated the nation's homes. Moreover, this important New England industry was located not too far away from "Newport."

Braga's "Judith Melo" wishes to convey not only to mainstream readers but also to Portuguese immigrants, Portuguese Americans, and other ethnics that there is certainly more of Portugal in American culture than people often wish to acknowledge or perhaps know about. In addition, the lines "Providence/ smile, sneer, smite/ your dark Semite/ countenance" are ironical. It is not Providence or God, says Braga, but rather mainstream America that has viewed Jews as possessing dark complexions, often comparing them to blacks as Karen Brodkin has shown in How Jews Became White Folks and What That Says about Race in America (2). In other words, it is the city of Providence, Rhode Island, where members of the dominant culture would sneer at her despite her people's contribution to their culture.

Other poems within this subgroup also stress how firmly Braga is rooted in the culture of his ancestors. Not only are such poems as "Ash Wednesday," "Codfish Cakes," and "Bacalhau" a substantiation of this, they also highlight how specific Portuguese beliefs, traditions, and ethnic foods are preserved within these "ethnic enclaves." While "Ash Wednesday" attests to the Catholic fervor of the Portuguese, the poem "Codfish Cakes" points to the Catholic observance of a fish diet on Fridays during Lent:

No meat today, don't ask!

No red sacrifice, instead the sea

will confess our sins in white

make us pure in a frying pan. 


\section{Ethnic Studies Review Volume 27: 1}

It's Fri-day, herbs, black aprons

dress friends - mackerel, flounder, cod

Parsley, onions, green sauce anointed

fill our souls with sanctity marine.

In this poem Braga touches upon quintessential aspects of life in a Portuguese fishing community. In addition it highlights the gender roles in this fishing town. Whereas the men are the ones who risk their lives at sea to provide for their families, the women, in contrast, are depicted as housewives, routinely cooking and raising their children. Traditionally, the widows put on "black aprons" or "shawls" so as to mourn their shipwrecked husbands. Others simply wear dark clothes all the time since there is no joy when a loved one is away for days or months at a time. Fishermen, their wives believe, only come back to life when coming ashore. The mood in this poem is marked by a certain feeling of fate ("fado") and nostalgia ("saudade"), aspects which some believe characterize the Portuguese temper. The perils involved in catching codfish in Newfoundland for about half a year, the storms and the imminent shipwrecks, and the wives or mothers who long for their husbands or sons are aspects this poem touches upon--even if indirectly. With the sea possessing such a symbolic value in Portuguese culture (epitomized by Portugal's role in the age of European explorations and its fishing subculture and traditions), the sea has, indeed, shaped the Portuguese outlook on life: that of a people subject to its whims. Not only does this poem attest to this fish diet during Lent as a community ritual, it also stresses the cultural and religious roles of women:

Codfish cakes sizzle in holy oils greasy hosts dished out to each in kitchens of briny Ports shawls chanting waves of the catch.

Salty patties, water, poesy, place make the sea our sod, sanctuary as we sail through centuries, grace, eating codfish cakes, kale, statuary (29). 
The poem's religious diction in such phrases as "red sacrifice," "confess our sins in white," "pure," "holy oils," and "sanctuary" further attest to these women's Catholic beliefs and how they cling to God since He is the only One capable of bringing their loved ones ashore. The religious imagery contained in the line "greasy hosts dished out" associates women with the holy Eucharist and, presumably, Christ's Last Supper, given the time of the year, but also attests to their role within the Roman Catholic Church. Women, more than men, found in the Church an outlet for a more meaningful life. A poem centering on a popular Portuguese foodstuff also has the effect of highlighting the Catholic fervor of the people living in this Portuguese American community--especially the women.

"Bacalhau" is a hymn to all the fishermen who sail to Newfoundland to capture codfish:

In search of hallowed cod,

all salted, all preserved,

in high rubber boots shod,

'Guees sail, for brine reserved.

Hauled into port, the fish,

loyal friends sacrificed,

dressed in oils, eggs, the dish

in garlic, onions diced

with olives, potatoes,

lemon and paprika,

for some with tomatoes,

Bacalhau America

in ethnic savours best.

With memories repast,

dark seaweed spirits rest

by sirens lured, barques past.

Although codfish cakes are a Portuguese delicacy, their taste, as the poem reminds us in the last strophe, is often bitter if we recall those unfortunate sailors whose "spirits" and bodies were trapped in the "dark seaweed." By capitalizing "Bacalhau 


\section{Ethnic Studies Review Volume 27: 1}

[codfish] America," Braga wishes to stress its importance in Portuguese gastronomy and how these traditions are kept alive in the Portuguese "ethnic enclaves" of America, a land that has often been hostile towards Otherness. As in the previous poem, "Bacalhau" brings to the fore quintessential aspects of Portuguese culture and ways, namely the Catholic fervor of the Portuguese, Portugal's nautical culture, and the unpredictability of life--all of which have shaped the people under consideration.

Moreover, Braga wishes to attach a sense of sacredness to the lives of these fishermen and their catch since there is so much at stake. The poem is also replete with religious overtones. While Braga is stressing the Catholic fervor of the Portuguese through the Eucharistic connotation embedded in the poem, it is possible that he may also wish to establish a parallel between the lives of these men and the quest for the Holy Grail. Whether they will or will not encounter what they are looking for lies in the hands of God.

The other subgroup of poems stresses Braga's fascination with, pride in, and knowledge of the culture of his ancestors. "Cravo" is a homage to the Democratic Revolution that took place in Portugal on April 25, 1974, and that marked the end of a forty-eight year Fascist dictatorship. It is also known as the carnation ("cravo") revolution since there was little shedding of blood. With Marcello Caetano's (the successor of Salazar) fascist régime offering little resistance, the military quickly took control of the situation as the bystanders and sidewalk florists in Lisbon cheered them on. Instead of bullets, the soldiers placed the red carnations from the florists' stands on their rifles as a token of peace and victory. Braga is fully aware that this episode is a cornerstone in twentieth-century Portuguese history since it brought a sense of hope for the future. Moreover, it represented the downfall of the Portuguese colonial empire:
A baroque calyx
stirs in my cup
as I read the headlines:
April 25, Captains' Coup.
My morning festooned
with serrated cravos, 
hopes, awaits dawning

vermilion phallus Portingale

While the phallic images contained in "calyx," "cravos," and "vermilion phallus Portingale" attest to the energy and determination of these soldiers, the poem pays tribute to those who partook in this revolution. It also celebrates Portugal's glorious past represented by the Discoveries in the sixteenth century. In addition, it stresses the role of Luís de Camões ("one-eyed poets"), the author of The Lusiads (1572), Portugal's great epic poem that celebrates Vasco da Gama's discovery of the sea-route to India in 1498:
Melodiously
like a field of blue
Azorean hydrangeas,
One-eyed poets bloom
in verdant, sombre humus,
Afric blossoms, violet hues
of crucified sails in late
spice-scenting sun,
voyages, navigation of lost
caravels assimilated in Cristo.

Not only is Braga proud of his Azorean heritage represented by the emblematic "Azorean hydrangeas," he is fascinated by Portugal's role in uniting the world with its "caravels," that is, Europe with Africa ("Afric blossoms") and India, with its "spicescenting sun."

Portugal's moment of glory, Braga reminds us, came to an end when King Sebastian, anxious to capture Portugal's former strongholds in North Africa (Morocco), was captured in Al-Kasir al-Kabir:

\section{The afternoon caresses \\ the monocled Dom Sebastian \\ in the blaspheming ruddy sun \\ of Maroc sands, Alcasar-Kebir;}

Never returning to Portugal and without a legitimate heir to the throne, Philip II, the Spanish monarch, immediately stepped in so as to claim the Portuguese throne in 1580. This "madness," Braga claims, cost the Portuguese their independence for sixty 


\section{Ethnic Studies Review Volume 27: 1}

years. While aiming to establish a parallel between both moments in Portuguese history, that is, during the Spanish annexation of Portugal and during the forty-eight year fascist dictatorship, the Portuguese, Braga claims, experienced oppression, misery, and poverty. During both periods, the Portuguese had to wait for better days:

\section{Lusian Cravo and Tome sown by Antonio \\ burst forth in the mud puddle perfuming my saucer \\ with revolution, empire's freedom.}

While António de Spínola became one of the emblematic figures of the revolution, Mário Soares and Álvaro Cunhal had lived in exile due to their leftist political views. With the revolution under way, however, Cunhal supported a more radical Communist commitment whereas Soares was more moderate and eventually thwarted Cunhal's influence after the first months of the revolution when Portugal, in 1975, was on the verge of becoming a Soviet-satellite country. Both, however, are now regarded as emblems of resistance and their aid in bringing down the dictatorship cannot be overlooked, as Braga tries to remind us in the lines "Spínola, Soares, Cunhal/but where is the dark, light/ demure Manueline Rosa?" (46-47). Braga's interest in these matters is his way of acknowledging the extent to which first and second generations of Portuguese in America were aware of-and interested in-the political situation in the old country. Their break with the Old World was never complete. Not only does this poem reflect the author's pride in his ancestral culture, it also reflects the ways in which he identifies himself with the heroes he has listed. He truly admires their heroism and determination, especially in times when the nation was plunged in uncertainty and despair.

"In the Glass Dome" touches upon the notion of a past that is crystallized in the poet's mind, replete with stories that had been conveyed to him by his grandmother and from which he draws spiritual sustenance. As in so many ethnic literatures, the figure of the grandmother is emblematic, for she is the liaison between the ancestral culture and the grandson. A very religious 
woman, she is the one who caters to his need for ethnic materials. He, in turn, is the one who gives shape to the stories she had narrated to him much earlier. The fragments of life in a fisherman's community such as the ones alluded to below are a fine substantiation of the poet's indebtedness:

It's all in the glass dome:

hours with Grandmother all alone,

the saints, the candles, the neighbor woman, teas, nights saying the rosary It's all in the glass dome.

It's all in the glass shade: angels, youth's streets, hushed voices, holy water, high Masses sung in the temple It's all in the glass shade.

It's all in the glass cover:

old ladies, fishmongers, bakers:

- "Tell us what you ate today."

- "I ate fried fish and hot bread" -

It's all in the glass cover.

In Grandmother's glass dome 'tis

All there born in bloom, mourning gardens, smiles, sunflowers, little birds, autumns, suns -

It's all in the glass dome (42).

While this poem attests to Braga's Catholic upbringing, the religious fervor of his grandmother, and the evenings spent with her as she fingered the decades on the rosary, it also casts a brief glance at the time when the poet used to hang out with his friends in what he refers to as "youth's streets," an aspect he dwells on more at length in "Below the Hill." The reference to the "old ladies, fishmongers, bakers" allows us to peek at moments in an ethnic community. Buying fish at the fishmonger's or Portuguese rolls and sweet bread at the local bakery is yet another opportunity to listen to the latest news and gossip. 


\section{Ethnic Studies Review Volume 27: 1}

Not only these but the lavish flower and vegetable gardens the Portuguese grow-and, presumably, his grandmother as well-in their backyards are a source of materials from which the poet can draw from to write poems and stories. As Fred L. Gardaphé has shown, the grandparent figure is at the heart of ethnic writing (120). For the ethnic writer the grandmother figure and her grasp of the ancestral culture are the modern day equivalent of the muses of classical antiquity.

At first, "Portuguese Lullaby" may look like the poet's recollection of the bedtime lullabies his grandmother used to sing to him, but the poem is an important one because it attests to Braga's skill in pulling together different allusions to Portuguese history and culture. Its most intriguing aspect, however, is the poet's ability to hear his Azorean ancestors calling to him, reminding him of his cultural and ethnic background:

Sleep, child. It's late. You must go out to sea.

O lo-lo-ro chiar do mar, nanar.

Aquamarines, ancestors, pearls

I hear across generations

Blowing my paralytic sails

Calling me with divinity's

Ebb and flow, conscience, age's conch:

Sleep, child. It's late. You must go out to sea.

O lo-lo-ro chiar do mar, nanar.

Whalers, fishermen, company, Black beards, no land, no island home,

Maids, enclaves, baroque progeny

Newfoundlands, colonies, flotsam

Steer blood's briny imperative:

Sleep, child. It's late. You must go out to sea.

O lo-lo-ro chiar do mar, nanar.

Vovo's breasts, waves, feasts, lullabies

Chant like crucified caravels 
Lapping soul's circumference, shells.

Our crusader winds, cradles, kin

Tow azurely with sirens' ring:

Sleep, child. It's late. You must go out to sea.

O lo-lo-ro chiar do mar, nanar.

Not now but soon blue poesy,

Indies' rites, spirit's absolutes

Will bear me back from heresy

Drowning Thomas sacraments, roots

With pater noster's elements:

Sleep, saint. It's late. We must go out to sea.

O lo-lo-ro chiar do mar, nanar (63-64).

Like Whitman's "Out of the Cradle Endlessly Rocking," where the poetic voice recalls a childhood episode of a bird singing to him, which he later, as an adult, interprets as his role of solitary singer, in "Portuguese Lullaby" Braga has also come to the realization that his role consists in celebrating Portuguese American culture. A poem that on a first reading looks more like the call of the ethnic (to adapt Jack London), it also evokes other matters such as Azorean fishermen, their contribution to the local and New England whaling industries in the nineteenth-century, as well as the feeling of isolation typical of island life. On the one hand the image of the "crucified caravels" (sails stamped with Christ's cross) takes us back to the sixteenth century while on the other hand "circumference" echoes the age's desire to circumnavigate the world and reach uncharted lands as was the case with Magellan (Fernão de Magalhães), a Portuguese at the service of the Spanish crown. As readers, we notice how Braga felt compelled to pay tribute to the most remarkable woman in his life, his grandmother. Had it not been for her and her stories, one wonders if Portingales ever would have seen the light of day-at least in the form that we know.

With Braga, Portuguese American ethnic literature is evidently beyond an embryonic stage. The poems in Portingales are a far cry from the writings about America of José Rodrigues Miguéis and Jorge de Sena, which I have outlined at the begin- 


\section{Ethnic Studies Review Volume 27: 1}

ning of this essay. Whereas these writers expressed their interest and, most of the time, dismay, frustration, and anxiety about what America represented to them mostly in the Portuguese language, Braga's choice of English enabled him to "light out" for what these writers perceived as "uncharted land." Moreover, his status as a native speaker of English allowed him to reach out to greater audiences, which, in turn, made him a credible source when conveying to mainstream America what it means to grow up in America as a hyphenated Portuguese American.

\section{Notes}

1 In viewing Fall River as a "haunted Ghetto" where the Portuguese live their own ethnic experience, deeply entrenched in their own "ethnic enclave" (Gordon 227), Braga's perception calls into question Nancy Baden's contention that "the Portuguese have not been concentrated in the ghetto-like situation in which one lives exclusively the 'ethnic' experience as have blacks, Puerto Ricans, and Chicanos" (Baden 27). Portuguese Americans do tend to stay together and even avoid the mainstream, especially the first and the second generations. But with the third and subsequent generations, the process of assimilation of Portuguese Americans is quicker. As the historian and sociologist Leo Pap has pointed out two decades ago, assimilation of the Portuguese into the mainstream has been unsteady:

It has been said that immigrants from the Azores have been quicker to identify with America than those from mainland Portugal, and those from the western Azores quicker than those from São Miguel (Pap 220).

\section{References}

Baden, Nancy T. "Portuguese-American Literature: Does it Exist?" MELUS 6.1 (1979): 15-31.

Braga, Thomas. Portingales. Providence, R. I.: Gávea-Brown, 1981. 
Brodkin, Karen. How Jews Became White Folks and What That Says about Race in America. New Brunswick, NJ:

Rutgers UP, 1999.

Duarte, Maria Angelina et. al. "A Literatura Luso- Americana: Que Futuro? - Uma Mesa Redonda." Gávea- Brown 2. Providence, R.I.: Gávea-Brown, 1981. 14-32.

Gardaphé, Fred. L. Italian Signs, American Streets: The Evolution of Italian American Narrative. Durham: Duke UP, 1996.

Gordon, Milton M. "Assimilation in America." Rereading America. Ed. Gary Colombo, Robert Cullen, and Bonnie Lisle. New York: St. Martin's, 1989. 221-29.

Monteiro, George. "'The Poor, Shiftless, Lazy Azoreans': American Literary Attitudes Toward the Portuguese." Proceedings of the Fourth National Portuguese Conference: The International Year of the Child. Providence, R. I.: The Multilingual Multicultural Resource and Training Center, 1979. 166-97.

Pap, Leo. "Portuguese-American Literature." EthnicPerspectives in American Literature: Selected Essayson the European Contribution. Ed. Robert J. DiPietro and Edward Ifkovic. New York: MLA, 1983. 183-96.

The Portuguese-Americans. Boston: Twayne, 1981.Rogers, Francis M. "The Contribution by Americans ofPortuguese Descent to the U. S. Literary Scene." Ethnic Literatures Since 1776: The Many Voices ofAmerica. Ed. Wolodymyr T. Zyla and Wendell M.Aycock. Part 2. Lubbock, Texas: Texas Tech, 1978. 409-32. 